\title{
KEDUDUKAN SERTA FUNGSI DPR DALAM SISTEM KETATANEGARAAN NEGARA REPUBLIK INDONESIA
}

\author{
Muchlisin \\ Universitas Islam Negeri Sunan Ampel Surabaya \\ muchlisin.alfarabi@gmail.com
}

\begin{abstract}
The Indonesian state has institutions as a reflection of democracy. Which puts people as the holders of sovereignty. The institution is the house of representatives which is incorporated in the legislative power. In determining the membership of the house of representatives, it remains through the electoral mechanism using the electoral system or the election. This research uses normative juridical research by studying the source of primary law and the source of legal sequences that are either legislation or research results to be carried out an institutional theory approach. The institution has the duty and function in the part of the indonesian state administration system to represent the aspirations or interests of the people. In addition to the duties and function of these institutions have rights that are not owned by other institutions.
\end{abstract}

Keywords: Position, Function, State Governance.

\begin{abstract}
ABSTRAK
Negara Indonesia memiliki lembaga sebagai cerminan dari demokrasi. Yang mana meletakkan rakyat sebagai pemegang kedaulatan. Lembaga tersebut adalah Dewan Perwakilan Rakyat yang tergabung didalam kekuasaan legislatif. Dalam penentuan keanggotaan Dewan Perwakilan Rakyat tetap melalui Mekanisme pemilihan dengan menggunakan sistem pemilihan umum atau PEMILU. Lembaga tersebut memiliki tugas serta fungsi dalam bagian sistem ketatanegaraan. Penelitian ini menggunakan penelitian yuridis normatif dengan menelaah sumber hukum primer dan sumber hukum sekuder yang berupa perUndang-Undangan maupun hasil penelitian untuk kemudian dilakukan pendekatan teori kelembagaan. Negara Indonesia untuk mewakili aspirasi atau kepentingan rakyat. Selain tugas dan fungsi lembaga tersebut memiliki hak yang tidak dimiliki oleh lembaga lain.
\end{abstract}

Kata Kunci : Kedudukan, Fungsi, Tata Negara.

\section{PENDAHULUAN}

Pembahasan perihal suatu lembaga negara, berarti juga membahas mengenai alat kelengkapan yang ada didalam sebuah negara. Mengenai alat kelengkapan tersebut, yang berdasarkan teori klasik hukum negara meliputi kekuasaan eksekutif, legislatif, serta yudikatif. Dalam hal kekuasaan legislatif yang mewakili aspirasi rakyat adalah anggota parlemen atau yang biasa disebut dengan Dewan Perwakilan Rakyat.

DPR Mempunyai tugas dan fungsi yang telah diatur didalam Undang-Undang Nomor 17 Tahun 2014 yang telah diubah dalam Undang-Undang Nomor 13 Tahun 
2019. Oleh karenanya, DPR menjadi bagian penting dalam sistem ketatanegaraan Indonesia untuk menjalankan fungsi negara juga untuk menjalankan fungsi pemerintahan secara aktual, terlebih dalam menampung serta mewujudkan aspirasi rakyat Indonesia.

Oleh karena itu dalam hal ini penulis akan menjelaskan tugas dan fungsi lembaga Dewan Perwakilan Rakyat. Sehingga dalam hal ini terwujudnya pemahaman atas batas tugas dan fungsi lembaga Dewan Perwakilan Rakyat.

\section{METODELOGI}

Penelitian ini menggunakan penelitian yuridis normatif. Metode penelitian yuridis normatif ${ }^{1}$ dilakukan melalui studi kepustakaan yang menelaah sumber hukum primer dan sumber hukum sekuder yang berupa perUndang-Undangan maupun hasil penelitian. Kemudian berdasarkan sumber hukum tersebut dilakukan pendekatan teori kelembagaan.

\section{PEMBAHASAN}

DPR merupakan lembaga perwakilan rakyat yang mempunyai kedudukan sebagai lembaga negara. Dewan Perwakilan Rakyat Republik Indonesia atau yang lebih dikenal dengan DPR-RI atau DPR merupakan salah satu lembaga Tinggi negara yang tergabung dalam lembaga legislatif di dalam sistem ketatanegaraan Indonesia sebagai lembaga perwakilan rakyat. Dewan Perwakilan Rakyat terbentuk dari anggota partai politik yang berperan sebagai peserta pemilihan umum yang telah dipilih melalui mekanisme pemilihan umum. ${ }^{2}$

Negara Indonesia merupakan negara kesatuan yang berbentuk Republik sesuai dengan Pasal 1 ayat (1) Undang-Undang Dasar Negara Republik Indonesia Tahun 1945 yang selanjutnya disingkat UUD NRI 1945. Bahwa kekuasaan pemerintah harus berlandaskan UUD NRI 1945. ${ }^{3}$ Didalam UUD NRI 1945 Pasca Amandemen, terdapat suatu pergeseran kekuasaan antara presiden dan DPR. Hal tersebut berada pada fungsi legislasi yang sebelumnya menjadi kekuasaan seorang presiden, maka setelah terjadinya amandemen UUD NRI 1945 fungsi legislasi berpindah menjadi kekuasaan DPR sebagaimana yang termaktub dalam Pasal 5

\footnotetext{
${ }^{1}$ Ronni Hanitijo Soemitro, Metode Penelitian Hukum dan Jurimetri, Ghaila Indonesia, Jakarta, 1998, h. 10.

${ }^{2}$ Pasal 67 dan 68 Undang-Undang No 13 Tahun 2019 Tentang MPR, DPR, DPD, dan DPRD.

3 Ahmad Munir, and Moh Hudi. "Keadilan Dalam Retribusi Parkir Berlangganan." Mimbar Yustitia 2.2 (2018): 214-222.
} 
ayat (1) Amandemen UUD NRI 1945. Pasal tersebut menjelaskan bahwa, Presiden berwenang mengajukan.rancangan Undang-Undang kepada DPR. Pasal 20 bahwa, DPR memegang kekuasaan membentuk Undang-Undang. Dalam hal ini perlu digaris bawahi bahwa titik berat kekuasaan legislasi nasional yang pada mulanya berada pada seorang presiden beralih kepada DPR.

Sebagai lembaga perwakilan rakyat, DPR mempunyai tugas-tugas sebagai berikut: ${ }^{4}$

a. DPR berwenang melakukan penyusunan, pembahasan, penetapan, sekaligus menyebarluaskan yang termasuk program legislasi nasional serta rancangan Undang-Undang.

b. DPR melakukan penerimaan rancangan Undang-Undang yang sebelumnya diajukan oleh DPD tentang otonomi daerahmenerima rancangan UndangUndang yang diajukan oleh DPD berkaitan dengan otonomi daerah, hubungan pusat dengan daerah, pembentukan dan pemekaran serta penggabungan daerah, pengelolaan sumber daya alam dan sumber daya ekonomi lainnya, serta yang berkaitan dengan keseimbangan keuangan pusat dan daerah.

c. DPR melakukan kegiatan pengawasan terhadap jalannya Undang-Undang, APBN, serta kebijakan pemerintah.

d. DPR melakukan pembahasan serta menindaklanjuti adanya hasil pemeriksaan atas terjadinya pengelolaan dan pertanggungjawaban keuangan negara yang telah disampaikan oleh Badan Pemeriksa Keuangan (BPK).

e. DPR berhak menyetujui terhadap pemindahan aset negara yang menjadi kewenangannya berdasarkan ketentuan peraturan perUndang-Undangan dan terhadap perjanjian yang berakibat luas dan mendasar bagi kehidupan rakyat yang terkait dengan beban keuangan negara.

f. Menyerap, menghimpun, menampung, dan menindak lanjuti aspirasi masyarakat; dan

g. Serta menjalankan tugas-tugas lain yang sudah diatur dalm UndangUndang.

Lembaga negara dalam menjalankan fungsinya harus didasarkan pada kewenangan dasar yang diatur oleh peraturan perundang-undangan, sehingga tindakan pemerintah dapat dianggap sah. ${ }^{5}$ Selanjutnya fungsi DPR dalam Amandemen UUD NRI 1945 BAB VII Pasal 20A ayat (1) Jo. Pasal 69 ayat (1) huruf a-c Undang-Undang. No. 2 Tahun 2018 tentang MPR, DPR, DPD, DPRD (MD3) bahwa DPR mempunyai fungsi sebagai berikut. legislasi, fungsi anggaran

\footnotetext{
${ }^{4}$ Pasal 72 UU Nomor 13 Tahun 2019 tentang MPR, DPR, DPD, DPRD.

${ }^{5}$ Sadjiono, Bab-bab Pokok Hukum Administrasi Negara, LaksBang, Yogyakarta, 2011, h. 58. Dikutip dalam Muwahid, Muwahid. "Kewenangan Pemerintah Dalam Pengadaan Tanah Untuk Kepentingan Umum." al-Daulah: Jurnal Hukum dan Perundangan Islam 8.2 (2018): 318-345.
} 
(budgeting), dan fungsi pengawasan (control). Kertiga fungsi tersebut dijalankan dalam kerangka representasi rakyat, dan melaksanakan politik luar negeri berlandaskan peraturan perundang- undangan. Yang dimaksud dengan ketiga fungsi tersebut adalah yakni fungsi legislasi, fungsi anggaran, dan fungsi pengawasan. ${ }^{6}$

Fungsi legislasi tersebut yakni membentuk Undang-Undang yang kemudian dibahas dengan Presiden untuk mendapat persetujuan bersama. Usulan Rancangan Undang-Undang dapat berasal dari DPR, Presiden, atau DPD. Hal ini menunjukkan bahwa DPR tidak bekerja sendiri didalam merumuskan maupun merancang Undang-Undang.

Dewan Perwakilan Rakyat merupakan pemegang kekuasaan legislatif. Kekuasaan legislatif merupakan kekuasaan yang pertama kali mencerminkan adanya kedaulatan rakyat. Hal tersebut termasuk Kegiatan bernegara, yaitu untuk mengatur kehidupan bersama. Oleh karenanya dalam hal menetapkan suatu peraturan harus diberikan kepada lembaga perwakilan rakyat atau parlemen yang di Indonesia dipegang oleh Dewan Perwakilan Rakyat.

Terdapat tiga hal yang mana harus dirumuskan oleh para wakil rakyat, yaitu: peraturan terhadap pengurangan hak serta kebebasan warga negara, peraturan terhadap pembebanan harta kekayaan warga negara, serta peraturan terhadap pengeluaran-pengeluaran yang dikeluarkan oleh lembaga negara. Peraturan terhadap ketiga hal tersebut hanya dapat dilakukan dengan persetujuan warga negara sendiri, dengan perantara wakil-wakil mereka di parlemen.

Fungsi legislasi ditetapkan dalam Pasal 5 ayat (1), Pasal 20, Pasal 21 ayat (1) dan Pasal 22 Undang-Undang Dasar 1945, sebelum adanya perubahan pertama Undang-Undang Dasar 1945. Setelah perubahan pertama UUD NRI 1945 fungsi legislasi diatur dalam pasal 20 UUD NRI 1945 yang menyatakan bahwa Dewan Perwakilan Rakyat memegang kekuasaan membentuk Undang-Undang. ${ }^{7}$

Hasil amandemen UUD NRI 1945 menentukan bahwa fungsi legislasi Dewan Perwakilan Rakyat menimbulkan konsekuensi yuridis bagi Dewan Perwakilan Rakyat, antara lain:

\footnotetext{
${ }^{6}$ Pasal 20 A ayat (1) Undang-Undang Negara Republik Indonesia Tahun Dasar 1945. Pasal 69 ayat (1) UU. No. 13 Tahun 2019 tentang MPR, DPR, DPD, DPRD.

${ }^{7}$ Undang-Undang Negara Republik Indonesia Tahun 1945, 15.
} 
a. DPR berkewajiban menyusun prioritas Rancangan Undang-Undang yang sesuai dengan kebutuhan masyarakat pada umumnya.

b. DPR dapat menerima masukan ataupun usulan dari masyarakat atau Lembaga Swadaya Masyarakat (LSM).

c. DPR dapat membuat sendiri draf Rancangan Undang-Undang.

d. DPR dapat melakukan kerjasama dalam hal penyusunan draf Rancangan Undang-Undang.

e. DPR mempunyai kewajiban melakukan pengawasan terhadap UndangUndang yang telah berlaku selama ini.

f. DPR mempunyai kewajiban melakukan inventarisasi dan evaluasi masalah terhadap Undang-Undang yang dianggap sudah tidak relevan dengan kondisi saat ini.

Undang-Undang di negara Indonesia telah memberikan kekuasaan berupa pembentukan Undang-Undang kepada Dewan Perwakilan Rakyat, tetapi tetap memberikan hak kepada pemerintah untuk mengajukan Rancangan UndangUndang kepada Dewan Perwakilan Rakyat. Tujuan dari kebijakan pergesaran kekuasaan dalam pembentukan Undang-Undang ke tangan Dewan Perwakilan Rakyat didasarkan keinginan untuk menerapkan sistim pemerintahan yang demokratis berdasarkan konsep distribution of power dan tegaknya mekanisme checks and balances antar lembaga Negara. ${ }^{8}$

Ketentuan tersebut mampu dilaksanakan dengan baik oleh Presiden dan Dewan Perwakilan Rakyat sebagai wujud prinsip checks and balances antara kedua lembaga tersebut. Akan tetapi terkadang terjadi perbedaan pendapat sehingga tidak terjadi kesepakatan antara kedua belah pihak. Sebagaimana dalam revisi UndangUndang tentang Pemilihan Kepala Daerah, Presiden tidak sepakat dengan Dewan Perwakilan Rakyat dan pada ahirnya Presiden mengeluarkan Peraturan Pengganti Undang-Undang (Perpu). ${ }^{9}$

Terdapat suatu frasa "untuk dibahas bersama dalam pasal 23 ayat (2) UUD NRI 1945 setelah amandemen yang menimbulkan suatu pertanyaan tentang kedudukan kedua lembaga yaitu presiden dan DPR dalam pembahasan RUU APBN. Hal tersebut sangat penting dikarenakan terdapat ketentuan pasal 23 ayat (3) UUD NRI 1945 setelah amandemen yang menyatakan apabila DPR tidak

8 A.M. Fatwa, Melanjutkan Reformasi Membangun Demokrasi, Raja Grafindo Persada, Jakarta, 2004, h. 97-100.

http://www.voaindonesia.com/content/presiden-sby-akan-keluarkan--perpu-terkait uupilkada/2468436.html, diakses pada 29 Februari 2019. 
menyetujui RUU APBN yang diusulkan oleh Presiden, maka pemerintah menjalankan APBN tahun lalu.

Dalam hal ini fungsi budgeting adalah membahas serta memberikan persetujuan atau tidak memberikan persetujuan terhadap suatu rancangan UndangUndang tentang APBN yang diajukan oleh Presiden. UUD NRI 1945 Pasal 20A ayat (1) menyatakan bahwa DPR memiliki suatu wewenang yang kuat dalam proses penetapan Anggaran Pendapatan dan Belanja Negara atau APBN. Hal ini dapat dilihat juga dari ketentuan dalam Pasal 23 ayat (3) UUD NRI 1945 yang menyatakan bahwa Anggaran Pendapatan dan Belanja Negara yang diajukan oleh pemerintah harus mendapat persetujuan terlebih dahulu dari Dewan Perwakilan Rakyat.

Selanjutnya dalam menggunakan penafsiran sistematis maka keterkaitan antara pasal 23 ayat (2) dan (3) tersebut menunjukkan penjelasan ataupun penegasan bahwa kedudukan DPR adalah lebih tinggi dibandingkan Presiden dalam pembahasan RAPBN. Hal ini karena DPR yang memberikan kata setuju atau tidak setuju. Maknanya disitu adanya hak budget DPR. ${ }^{10}$

Merupakan fungsi untuk melakukan proses pengawasan (Controlling) terhadap pelaksanaan UUD NRI 1945, maupun Undang-Undang serta peraturan pelaksanaannya. ${ }^{11}$ Fungsi tersebut diperlukan sebagai upaya mengontrol jalannya pemerintahan, yang menyasar terhadap kesesuaian kebijakan yang telah ditetapkan atau justru terjadi hal yang menyimpang. Implementasi konsep Trias Politica, kekuasaan tidaklah terpisah satu sama lain secara tegas karena ada unsur pembagian tugas dalam membuat kebijakan. Kekuasaan legislatif dijalankan secara bersama oleh Dewan Perwakilan Rakyat berasama Presiden.

Kebersamaan terjalin antara Dewan Perwakilan Rakyat dengan Presiden, dengan pentingnya meletakkan landasan yuridis untuk menentukan hal-hal apa yang ingin dicapai melalui kegiatan pembangunan dan berapa besar anggaran yang dibutuhkan. Setelah kesepakatan dicapai dituangkan dalam penetapan Anggaran Pendapatan dan Belanja Negara, pemerintah bertugas mewujudkan programprogram pembangunan. Sedangkan Dewan Perwakilan Rakyat memiliki tugas

\footnotetext{
1996, h. 8 .

${ }^{10}$ Jimmly Assiddiqie, Pergumulan Peran Pemerintah terhadap APBN, UI Press, Jakarta,

${ }^{11}$ Bagir Manan, Konvensi Ketatanegaraan, FH UII Press, Yogyakarta 2006, h. 11.
} 
melakukan pengawasan terhadap keseluruhan program pembangunan dengan mengoreksi adanya penyimpangan atau tidak adanya suatu penyimpangan. ${ }^{12}$

\section{KESIMPULAN}

Dewan Perwakilan Rakyat atau lebih dikenal dengan DPR merupakan salah satu lembaga yang berada dalam struktur ketatanegaraan Indonesia. Yang mana lembaga tersebut termasuk lembaga legislatif didalam struktur ketatanegaraan Indonesia. Lembaga tersebut memiliki tugas dan fungsinya yang sudah diatur didalam Undang-Undang Nomor 2 Tahun 2018 tentang perubahan kedua atas Undang-Undang Nomor 17 Tahun 2014. Tentang tugas DPR diatur didalam Pasal 72 Undang-Undang No. 2 Tahun 2018. Sedangkan fungsi DPR diatur didalam pasal 20A ayat (1) Jo. Pasal 69 ayat (1) huruf a-c Undang-Undang No. 17 Tahun 2018. Dewan Perwakilan Rakyat dalam menjalankan tugas dan fungsinya saling bekerja sama dengan lembaga yang lainnya sehingga terjadinya chake and balance didalam sistem ketatanegaraan Indonesia

\section{DAFTAR PUSTAKA}

A.M., Fatwa, Melanjutkan Reformasi Membangun Demokrasi, Raja Grafindo Persada, Jakarta, 2004.

Bagir, Manan, Konvensi Ketatanegaraan, FH UII Press, Yogyakarta 2006.

Jimly, Assiddiqie, Pengantar Ilmu Hukum Tata Negara, PT Raja Grafindo Persada, Depok, 2009. Jakarta, 1996.

Munir, Ahmad, and Moh Hudi. "Keadilan Dalam Retribusi Parkir Berlangganan." Mimbar Yustitia 2.2 (2018).

Muwahid. "Kewenangan Pemerintah Dalam Pengadaan Tanah Untuk Kepentingan Umum." al-Daulah: Jurnal Hukum dan Perundangan Islam 8.2 (2018).

Sadjiono, Bab-bab Pokok Hukum Administrasi Negara, LaksBang, Yogyakarta, 2011.

Soemitro, Ronni Hanitijo, Metode Penelitian Hukum dan Jurimetri, Ghaila Indonesia, Jakarta, 1998.

\footnotetext{
${ }^{12}$ A.M. Fatwa, Op. Cit., h. 209.
} 